\title{
Comprehensive Assessment on Factors Affecting Students' Performance in Basic Computer Programming Course towards the Improvement of Teaching Techniques
}

\author{
Regina A. Garcia \\ College of Computer and Information \\ Sciences \\ King Saud University
}

\author{
Lilac A. Al-Safadi \\ College of Computer and Information \\ Sciences \\ King Saud University
}

\begin{abstract}
Learning how to program correctly is a challenging task for both the students and the instructors. In this regard, basic computer programming course's instructors play a significant role for the students, as what they will learn in an introductory course will be the foundation for their further programming studies. This paper studies the factors of both instructors and students that affect the latter's performance in the basic computer programming course offered by the Information Technology Department (IT Department) of King Saud University (KSU). A questionnaire was distributed to and retrieved from target respondents for data collection. Frequency count and chi-square test were used to analyze the responses gathered. Results showed that there is no significant relationship between the students' factors and instructors' factors as perceived by students in the course. However, the respondents noted the most important to least important factors that will assist the university and its faculty to concentrate on the areas that needs to be maintained and areas that needs to improve in teaching and learning process which will lead to the improvement of teaching techniques in computer programming courses but also continuous provision of quality education in Saudi Arabia.
\end{abstract}

\section{Introduction}

A computer program is a set of commands or instructions. Formally, Winters [13] defined it as a chain of instructions a computer has to perform. He classified three fundamental elements which characterize programs: instructions that need to be carried out, order in which the instructions are to be carried out and, data needed to do instructions.

The act of writing these computer programs is programming which requires skills that will be an asset of a person in his/her chosen career. In fact, Robins et al. [3] stated that programming is a very useful skill and can be a rewarding career. They mentioned that in recent years the demands for programmers and students' interest in programming have grown rapidly, and introductory programming courses have become increasingly popular. On the other hand, they pointed out that learning to program is hard however interesting and challenging.

Even though the IT profession offers a promising career in this information age, still it does not seem appealing to many youths. An IT Report released by the Communications and Information Technology Commission (CITC) in Saudi Arabia showed that during 2010-2014, the highest growth in demand is expected for software developers, followed by application system analysts, IT project managers, IT consultants. Despite the current local \& global trend to use is information technology, if someone were to keep track of the number of students who chose a programming-related career, they would be amazed to see that the number has diminished compared with the past two decades when IT became one of the in demand professions all over the world. This is actually true most especially when comparing the number of individuals in terms of gender. This not only in Saudi Arabia but also worldwide that there are few percentage of women are interested in computer science and information technology fields rather than their male counterparts. As a proof, Lucio [15] stated that in 1985, about 37 percent of those earning computer science degrees in the U.S. were women but in 2010 , that number fell to 18 percent, according to data from the National Center for Women \& Information Technology. The IT Report by CITC [13] revealed that these software developers are very difficult to find and that educational institutions should focus on graduating more programmer and software - the professions which are currently more difficult to find in the market.

Indeed, programming requires problem-solving and analytical skills, and creating a program would seem to be difficult for beginners, but one needs to understand that in order for a student to achieve a degree in IT or computing, they need to at least learn the basics of how to write programs in a particular programming language. 
There have been numerous researches with regard to the factors affecting students' performance in programming courses, but still the problem remains. The only probable major aspects that affect students' performance in the said course would be teaching techniques and students' readiness. As a resolution for assisting IT institutions which will aid the improvement of both aspects, this research is intended to help the students become competitive locally and internationally, which is one of the requirements of the Information and Communications Technology (ICT) sector.

Fig. 1 clearly shows that there are factors which are involved in the learning process of a computer programming course. During the process, learning styles are identified such as whether the student is innovative (learns from others), analytic (learns from lectures and analysis), shows common sense (learns from hands-on exercises), and is dynamic (learns alone) [7]. After the said process, the results would be an improvement of student's academic performance as well as instructors' teaching techniques in computer programming course.

Independent Variables

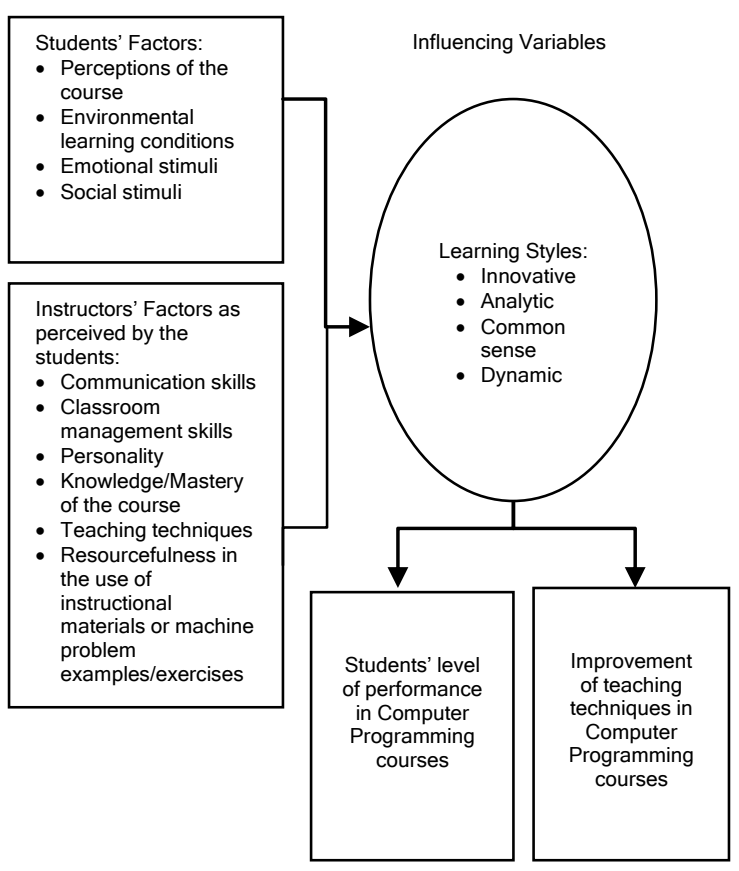

Figure 1. Research paradigm

This paper is organized as follows: in section 2 , the authors provide an overview of literatures and studies related to the field as well as the specific problem statement; section 3 describes the objectives and main purpose of this research; section 4 gives details about the research methods utilized; section 5 summarizes the findings and results obtained; section 6 presents the conclusions; and section 7 indicates the recommended course of action based on findings.

\section{Overview and Statement of the Problem}

Programming seems difficult and disheartening for most students on computer programming course. This truth has been proven by various authors. According to Pedroni [10], learning to program, as well as teaching programming, is a challenge. Want and Wong [6] pointed out that learning computer programming has been known to be difficult for many beginners. However, Rogerson and Scott [4] pointed out that among the barriers to learning programming are the following: programming students need to overcome, during the course of their studies, what appears to be the mastery of a completely new way of thinking, and inability to trace code. They stated that a considerable amount of effort and time may be required to code a fairly simple program, and finding mistakes is equally time-consuming. Also, they stressed that educators should focus on the individual student and be aware of both their knowledge level and preferred learning style.

The approaches and methods of teaching these programming courses have a huge contribution in learning. Ismail et al. [9] stated most programming courses are taught using the traditional approaches including a blend of lectures, readings and practical sessions. They found out that there is a lack of skills in analyzing problems among students, ineffective use of problem representation techniques for problem solving, ineffective use of teaching strategies for problem solving and coding, and lack of students' understanding and mastering the programming syntax and constructs. Xiahui [8] expressed that traditional teacher-centered learning strategies include such activities as lecturing, questioning and demonstrating which have been found to be inadequate for many students. He added that the teachers focus on what they want the students to learn and restrict their teachings to what the students might learn. Moreover, Chaparro et al. [5] stated that pair programming, the situation in which two programmers work side by side on the same piece of code, is a well-accredited approach to teaching programming. They emphasized that students who practice pair programming have shown better results on graded assignments and more satisfaction/less frustration on doing course projects.

With the above statements, it was clearly stated that there are factors that need to be considered by the instructors and students in order to enhance the level of students' performance in programming courses and through improving the teaching techniques being employed.

Hence, in this study, specifically, the answers to the following questions will be sought: 
1. What are the required characteristics of computer programming instructors as perceived by students in terms of:

a. Communication skills

b. Classroom management skills

c. Personality

d. Knowledge/Mastery of the course

e. Techniques used

f. Resourcefulness in the use of instructional materials or machine problem examples/exercises.

2. What are the characteristics of computer programming students in terms of:

a. Perceptions of the course

b. Environmental learning conditions

c. Emotional stimuli

d. Social stimuli

3. Is there any significant correlation between instructors' factors as perceived by the students and the latter's academic performance in the course?

\section{Objectives of the Study}

The main objective of the study is to determine the factors affecting students' performance which will lead to the improvement of the teaching techniques used in computer programming course. Specifically, these objectives are 1) to identify the characteristics of computer programming instructors as perceived by students, 2) to identify the characteristics of computer programming students, and 3 ) to identify the significant correlation between students' and instructors' factors as perceived by students in the former's academic performance.

\section{Research Methodology}

In this research, locale of the study, research method, respondents, research tools, validation of instruments, procedures in gathering needed data were analyzed. This also presented the statistical treatment that was employed in the analysis of the presentation of data.

\subsection{Locale}

The research was conducted in IT Department of KSU - Female Section, Al-Malaz Campus, AlMalaz, Riyadh, Saudi Arabia.

\subsection{Respondents}

The research utilized the students from Level 1 of the second semester of academic year 2010/2011 of Computer Programming 1 as its respondents which comprised a total of 25 students.

\subsection{Research Method}

Descriptive method utilized as the method of research. It is a purposive process of gathering, analyzing, classifying and tabulating data. Furthermore, the method is significant to understand the characteristics of each independent variable. By using observation and surveys using questionnaire, the researchers will be able to describe the responses given by the target respondents.

\subsection{Research Tool}

Provided questionnaire was the primary data employed to draw and to classify the objectives of the study. As for the preparation of this questionnaire, the master's thesis of Garcia [11] became the basis of each factor and its indicator. During the construction of the questionnaire, the instructors of basic computer programming course were consulted in order to have a questionnaire based on the culture and level of understanding of Level 1 students.

Also, follow-up informal interview among computer programming course instructors provided the secondary data to determine the problems based on the students' performance on the said course.

\subsection{Validation of Instrument}

Questionnaire was prepared and presented to the IT Department's faculty members for suggestions and criticisms. And after this, the questionnaire was finalized and was set to be administered at the end of the semester few days before final examination in order to have consistent and relevant responses.

\subsection{Data Gathering Procedure}

The research utilized the methods of research, and timely and relevant ideas. Prior to the administration of questionnaires to the target respondents, the authors asked permission from the Head of the IT Department for the dissemination of questionnaire to respondents. During dissemination, only 19 students were present.

\subsection{Statistical Treatment}

Statistics were used for the analysis and interpretation of data. It used descriptive type statistics where the purpose is to describe the existing conditions. Inferential type was employed to determine the significant relationship between variables. Also, frequency count was utilized for more descriptive view of the summarized data that was used in the research. And for the analysis of the significant correlation of factors in computer 
programming students' academic performance, chi square test was used. The test will provide a single number that adds up all the differences between the actual data and the data expected if there is no difference.

Below is the formula for chi-square $\left(\mathrm{x}^{2}\right)$ :

$$
\begin{array}{ll}
\mathrm{x}^{2} & =\quad \sum\left((\mathrm{O}-\mathrm{E})^{2} / \mathrm{E}\right) \\
\text { where } & \mathrm{x}^{2} \text { - chi-square } \\
& \sum \text { - the sum of } \\
& \mathrm{O} \text { - observed frequency } \\
& \mathrm{E} \text { - expected frequency }
\end{array}
$$

\section{Results and Discussion}

The following paragraphs discuss the findings of the study. The results in each table show the indicators for each factor together with the values of the frequency count $(\mathrm{O})$, and the values in parentheses represent as the expected frequencies (E). $\mathrm{O}$ is the actual number of samples while $\mathrm{E}$ is calculated based on multiplying the total number of $\mathrm{O}$ in a row per indicator and the total number of $\mathrm{O}$ in a column and divided by the grand total of $\mathrm{O}$ per factor. The evaluation scales used in each table are: $\mathrm{SA}=$ strongly agree, $\mathrm{A}=$ agree, $\mathrm{D}=$ disagree, and $\mathrm{SD}=$ strongly disagree, while other values used are: 1) degrees of freedom (df) which was computed as the product of the number of rows minus one and the number of columns minus one, 2) the most common level of significance at 0.05 which means that $5 \%$ probability is within the range of acceptable deviation, and 3) chi-square critical value from $x^{2}$ distribution table value at 0.05 level of significance.

What follows are the factors of computer programming instructors as perceived by students in terms of communication skills, classroom management skills, personality, knowledge/mastery of the course, techniques used and resourcefulness in the use of instructional materials or machine problem examples/exercises. To simplify, these factors are divided into two categories: 1) natural teaching skills which are considered as skills that naturally come out from the instructors meaning they are in-born traits of the instructors. These skills are: communication skills which make the instructors effective in teaching and this is their way to effectively deliver the lessons in class; classroom management skills is their ability to manage and lead the class and; personality is the reflection of who they are when they are teaching; 2) acquired teaching skills which instructors acquired through further enhancement of their chosen career such as further studies, seminars, conferences and professional social events. These includes: knowledge/mastery of the course; techniques used in teaching in order for

\begin{tabular}{|c|c|c|c|c|}
\hline Indicators & SA & A & D & SD \\
\hline \multicolumn{5}{|c|}{ Communication skills } \\
\hline c1 & $\begin{array}{c}10 \\
(9.81)\end{array}$ & $\begin{array}{c}7 \\
(6.47)\end{array}$ & $\begin{array}{c}1 \\
(2.51)\end{array}$ & $\begin{array}{c}1 \\
(0.21)\end{array}$ \\
\hline c2 & $\begin{array}{c}10 \\
(9.30)\end{array}$ & $\begin{array}{c}6 \\
(6.13)\end{array}$ & $\begin{array}{c}2 \\
(2.37)\end{array}$ & $\begin{array}{c}0 \\
(0.20)\end{array}$ \\
\hline c3 & $\begin{array}{c}11 \\
(9.30)\end{array}$ & $\begin{array}{c}4 \\
(6.13)\end{array}$ & $\begin{array}{c}3 \\
(2.37)\end{array}$ & $\begin{array}{c}0 \\
(0.20)\end{array}$ \\
\hline c4 & $8(9.30)$ & $\begin{array}{c}6 \\
(6.13)\end{array}$ & $\begin{array}{c}4 \\
(2.37)\end{array}$ & $\begin{array}{c}0 \\
(0.20)\end{array}$ \\
\hline c5 & $8(9.30)$ & $\begin{array}{c}8 \\
(6.13)\end{array}$ & $\begin{array}{c}2 \\
(2.37)\end{array}$ & $\begin{array}{c}0 \\
(0.20) \\
\end{array}$ \\
\hline \multicolumn{5}{|c|}{ Classroom management skills } \\
\hline $\mathrm{cm} 1$ & $\begin{array}{c}14 \\
(10.13)\end{array}$ & $\begin{array}{c}5 \\
(7.47)\end{array}$ & $\begin{array}{c}0 \\
(0.89)\end{array}$ & $\begin{array}{c}0 \\
(0.51)\end{array}$ \\
\hline $\mathrm{cm} 2$ & $\begin{array}{c}14 \\
(9.60)\end{array}$ & $\begin{array}{c}4 \\
(7.08)\end{array}$ & $\begin{array}{c}0 \\
(0.84)\end{array}$ & $\begin{array}{c}0 \\
(0.48)\end{array}$ \\
\hline $\mathrm{cm} 3$ & $\begin{array}{c}8 \\
(10.13)\end{array}$ & $\begin{array}{c}9 \\
(7.47)\end{array}$ & $\begin{array}{c}1 \\
(0.89)\end{array}$ & $\begin{array}{c}1 \\
(0.51)\end{array}$ \\
\hline $\mathrm{cm} 4$ & $\begin{array}{c}8 \\
(10.13) \\
\end{array}$ & $\begin{array}{c}9 \\
(7.47)\end{array}$ & $\begin{array}{c}1 \\
(0.89)\end{array}$ & $\begin{array}{c}1 \\
(0.51) \\
\end{array}$ \\
\hline cm5 & $\begin{array}{c}12 \\
(9.60)\end{array}$ & $\begin{array}{c}6 \\
(7.08)\end{array}$ & $\begin{array}{c}0 \\
(0.84)\end{array}$ & $\begin{array}{c}0 \\
(0.48)\end{array}$ \\
\hline $\mathrm{cm} 6$ & $\begin{array}{c}8 \\
(10.13)\end{array}$ & $\begin{array}{c}9 \\
(7.47)\end{array}$ & $\begin{array}{c}1 \\
(0.89)\end{array}$ & $\begin{array}{c}1 \\
(0.51)\end{array}$ \\
\hline $\mathrm{cm} 7$ & $\begin{array}{c}7 \\
(10.13)\end{array}$ & $\begin{array}{c}10 \\
(7.47)\end{array}$ & $\begin{array}{c}1 \\
(0.89)\end{array}$ & $\begin{array}{c}1 \\
(0.51)\end{array}$ \\
\hline $\mathrm{cm} 8$ & $\begin{array}{c}9 \\
(10.13)\end{array}$ & $\begin{array}{c}7 \\
(7.47)\end{array}$ & $\begin{array}{c}3 \\
(0.89)\end{array}$ & $\begin{array}{c}0 \\
(0.51)\end{array}$ \\
\hline \multicolumn{5}{|c|}{ Personality } \\
\hline $\mathrm{p} 1$ & $8(9.38)$ & $\begin{array}{c}10 \\
(7.35)\end{array}$ & $\begin{array}{c}0 \\
(0.68)\end{array}$ & $\begin{array}{c}0 \\
(0.60)\end{array}$ \\
\hline p2 & $8(9.90)$ & $\begin{array}{c}9 \\
(7.76)\end{array}$ & $\begin{array}{c}1 \\
(0.71)\end{array}$ & $\begin{array}{c}1 \\
(0.63)\end{array}$ \\
\hline p3 & $\begin{array}{c}10 \\
(9.38)\end{array}$ & $\begin{array}{c}8 \\
(7.35)\end{array}$ & $\begin{array}{c}0 \\
(0.68)\end{array}$ & $\begin{array}{c}0 \\
(0.60)\end{array}$ \\
\hline p4 & $\begin{array}{c}12 \\
(9.38)\end{array}$ & $\begin{array}{c}6 \\
(7.35)\end{array}$ & $\begin{array}{c}0 \\
(0.68)\end{array}$ & $\begin{array}{c}0 \\
(0.60)\end{array}$ \\
\hline p5 & $\begin{array}{c}11 \\
(9.90)\end{array}$ & $\begin{array}{c}6 \\
(7.76)\end{array}$ & $\begin{array}{c}1 \\
(0.71)\end{array}$ & $\begin{array}{c}1 \\
(0.63)\end{array}$ \\
\hline p6 & $\begin{array}{c}10 \\
(9.90)\end{array}$ & $\begin{array}{c}7 \\
(7.76)\end{array}$ & $\begin{array}{c}1 \\
(0.71)\end{array}$ & $\begin{array}{c}1 \\
(0.63)\end{array}$ \\
\hline p7 & $\begin{array}{c}11 \\
(9.38)\end{array}$ & $\begin{array}{c}7 \\
(7.35)\end{array}$ & $\begin{array}{c}0 \\
(0.68)\end{array}$ & $\begin{array}{c}0 \\
(0.60)\end{array}$ \\
\hline p8 & $\begin{array}{c}11 \\
(9.90)\end{array}$ & $\begin{array}{c}6 \\
(7.76)\end{array}$ & $\begin{array}{c}1 \\
(0.71)\end{array}$ & $\begin{array}{c}1 \\
(0.63)\end{array}$ \\
\hline p9 & $\begin{array}{c}11 \\
(9.90)\end{array}$ & $\begin{array}{c}5 \\
(7.76)\end{array}$ & $\begin{array}{c}1 \\
(0.71)\end{array}$ & $\begin{array}{c}2 \\
(0.63)\end{array}$ \\
\hline p10 & $\begin{array}{c}10 \\
(9.38) \\
\end{array}$ & $\begin{array}{c}6 \\
(7.35) \\
\end{array}$ & $\begin{array}{c}2 \\
(0.68)\end{array}$ & $\begin{array}{c}0 \\
(0.60) \\
\end{array}$ \\
\hline p11 & $7(9.90)$ & $\begin{array}{c}10 \\
(7.76)\end{array}$ & $\begin{array}{c}1 \\
(0.71)\end{array}$ & $\begin{array}{c}1 \\
(0.63)\end{array}$ \\
\hline p12 & $\begin{array}{c}11 \\
(9.38)\end{array}$ & $\begin{array}{c}7 \\
(7.35)\end{array}$ & $\begin{array}{c}0 \\
(0.68)\end{array}$ & $\begin{array}{c}0 \\
(0.60)\end{array}$ \\
\hline p13 & $5(9.38)$ & $\begin{array}{c}11 \\
(7.35)\end{array}$ & $\begin{array}{c}1 \\
(0.68)\end{array}$ & $\begin{array}{c}1 \\
(0.60)\end{array}$ \\
\hline
\end{tabular}
their students to learn the lesson very well and the resourcefulness in the use of instructional material for machine problem examples/exercises.
Table 1. Natural teaching skills

Table 1 shows the instructors factors in teaching skills category.

In terms of communication skills, indicators used are as follows: $\mathrm{c} 1$ - has the ability to explain subject matter clearly; c2 - ask questions relevant to the course; c3 - use of English language as a medium of 
communication in teaching; c4 - gives facts or opinions about content or procedures of the subject matter for each class meeting, and; c5 - expresses her own ideas about the subject matter for particular sessions/classes/meetings. Among these indicators, students noted that c1 obtained $89 \%$ of strongly agree and agree responses. This indicates that according to students' assessment, the instructors have the ability to explain very well on the level of their understanding. However, the results show that using df of 12 , a calculated $\mathrm{x}^{2}$ value of 8.17 which were computed using the $\mathrm{x}^{2}$ formula given previously is less than the critical value of 21.03. Thus, it indicates that there is no significant relationship between instructors' communication skill factor and students' academic performance in the course. Furthermore, it means that the amount of difference between the expected and actual data is likely due to chance.

In terms of classroom management skills factors, indicators used are as follows: $\mathrm{cm} 1$ - comes to classroom on time; $\mathrm{cm} 2$ - comes to class well prepared; cm3 - gives sufficient time for different topics or lessons; cm4 - maintains order and discipline in the classroom; cm5 - checks attendance; cm6 - gets the attention of the students who do not listen, are frequently absent and have other deficiencies; $\mathrm{cm} 7$ - achieves teaching objectives for the particular subject, lesson, or laboratory activities within a reasonable period of time; and cm8 - administers examinations/tests effectively and returns corrected papers and other students' work promptly. Among these indicators, students noted that $\mathrm{cm} 1$ obtained $100 \%$ of strongly agree and agree responses. This indicates that according to students' assessment, the instructors are doing their duties and responsibilities in their teaching careers. However, results show that using df of 21 , a calculated $x^{2}$ value of 22.17 which is less than the critical value of 32.67 is an indication there is no significant relationship between instructors' classroom management skills factor and students' academic performance in the course. Furthermore, it means that the amount of difference between the expected and actual data is likely due to chance.

And in terms of the personality factor, indicators used are as follows: p1 - approachable outside the classroom for consultation; p2 - shows enthusiasm when teaching; p3 - fair when dealing with students and when giving grades; $\mathrm{p} 4$ - encourages student to ask questions and express opinion freely; p5 respects and accepts students' ideas, suggestions and limitations; p6 - displays willingness to repeat the lesson when necessary; p7 - observes proper clothes/dress at all times; p8 - uses free time effectively/efficiently; p9 - observes the Instructors' Code of Ethics and other pertinent rules and regulations of the university; p10 - understands the example in moral and ethical behavior to students, peers and the community; p11 - shows creativity and energy in their performance; p12 - shows evidence of professional and cultural growth; and p13 - makes jokes that release tension but not at the expense of another student in the class. Among these indicators students noted that p3, p4, p7 and p12 obtained 95\% of strongly agree and agree responses. This indicates that instructors maintain a personality of being professional in their teaching career. However, results show that using df of 36 , a calculated $x^{2}$ value of 26.01, which is less than critical value of 51.00, is an indication that there is no significant relationship between instructors' personality factor and students' academic performance in the course. Furthermore, it means that the amount of difference between the expected and actual data is likely due to chance.

Table 2. Acquired teaching skills

\begin{tabular}{|c|c|c|c|c|}
\hline Indicators & SA & A & $\mathrm{D}$ & SD \\
\hline \multicolumn{5}{|c|}{ Knowledge/Mastery of the course } \\
\hline k1 & $\begin{array}{c}12 \\
(9.62)\end{array}$ & $\begin{array}{c}6 \\
(7.15)\end{array}$ & $\begin{array}{c}0 \\
(0.99)\end{array}$ & $\begin{array}{c}0 \\
(0.25)\end{array}$ \\
\hline k2 & $\begin{array}{c}8 \\
(10.15)\end{array}$ & $\begin{array}{c}9 \\
(7.55)\end{array}$ & $\begin{array}{c}1 \\
(1.04)\end{array}$ & $\begin{array}{c}1 \\
(0.26)\end{array}$ \\
\hline k3 & $\begin{array}{c}10 \\
(9.62)\end{array}$ & $\begin{array}{c}8 \\
(7.15)\end{array}$ & $\begin{array}{c}0 \\
(0.99)\end{array}$ & $\begin{array}{c}0 \\
(0.25)\end{array}$ \\
\hline k4 & $\begin{array}{c}9 \\
(9.62)\end{array}$ & $\begin{array}{c}6 \\
(7.15)\end{array}$ & $\begin{array}{c}3 \\
(0.99)\end{array}$ & $\begin{array}{c}0 \\
(0.25)\end{array}$ \\
\hline \multicolumn{5}{|c|}{ Techniques used } \\
\hline $\mathrm{t} 1$ & $\begin{array}{c}12 \\
(9.53)\end{array}$ & $\begin{array}{c}5 \\
(7.50)\end{array}$ & $\begin{array}{c}1 \\
(1.45)\end{array}$ & $\begin{array}{c}1 \\
(0.43)\end{array}$ \\
\hline t2 & $\begin{array}{c}10 \\
(9.53)\end{array}$ & $\begin{array}{c}7 \\
(7.50)\end{array}$ & $\begin{array}{c}1 \\
(1.45)\end{array}$ & $\begin{array}{c}1 \\
(0.43)\end{array}$ \\
\hline $\mathrm{t} 3$ & $\begin{array}{c}12 \\
(9.53)\end{array}$ & $\begin{array}{c}5 \\
(7.50)\end{array}$ & $\begin{array}{c}1 \\
(1.45)\end{array}$ & $\begin{array}{c}1 \\
(0.43)\end{array}$ \\
\hline t4 & $\begin{array}{c}3 \\
(9.03)\end{array}$ & $\begin{array}{c}9 \\
(7.10)\end{array}$ & $\begin{array}{c}5 \\
(1.38)\end{array}$ & $\begin{array}{c}1 \\
(0.40)\end{array}$ \\
\hline t5 & $\begin{array}{c}9 \\
(9.03)\end{array}$ & $\begin{array}{c}7 \\
(7.10)\end{array}$ & $\begin{array}{c}2 \\
(1.38)\end{array}$ & $\begin{array}{c}0 \\
(0.40)\end{array}$ \\
\hline t6 & $\begin{array}{c}9 \\
(9.03)\end{array}$ & $\begin{array}{c}9 \\
(7.10)\end{array}$ & $\begin{array}{c}0 \\
(1.38)\end{array}$ & $\begin{array}{c}0 \\
(0.40)\end{array}$ \\
\hline t7 & $\begin{array}{c}8 \\
(9.03)\end{array}$ & $\begin{array}{c}7 \\
(7.10)\end{array}$ & $\begin{array}{c}3 \\
(1.38)\end{array}$ & $\begin{array}{c}0 \\
(0.40)\end{array}$ \\
\hline t8 & $\begin{array}{c}8 \\
(9.03)\end{array}$ & $\begin{array}{c}8 \\
(7.10)\end{array}$ & $\begin{array}{c}2 \\
(1.38)\end{array}$ & $\begin{array}{c}0 \\
(0.40)\end{array}$ \\
\hline $\mathrm{t} 9$ & $\begin{array}{c}7 \\
(9.03)\end{array}$ & $\begin{array}{c}9 \\
(7.10)\end{array}$ & $\begin{array}{c}1 \\
(1.38)\end{array}$ & $\begin{array}{c}1 \\
(0.40)\end{array}$ \\
\hline \multicolumn{5}{|c|}{$\begin{array}{c}\text { Resourcefulness in the use of instructional } \\
\text { materials or machine problem } \\
\text { examples/exercises }\end{array}$} \\
\hline r1 & $\begin{array}{c}6 \\
(7.20)\end{array}$ & $\begin{array}{c}9 \\
(8.20)\end{array}$ & $\begin{array}{c}2 \\
(2.20)\end{array}$ & $\begin{array}{c}1 \\
(0.40)\end{array}$ \\
\hline r2 & $\begin{array}{c}9 \\
(7.20)\end{array}$ & $\begin{array}{c}7 \\
(8.20)\end{array}$ & $\begin{array}{c}2 \\
(2.20)\end{array}$ & $\begin{array}{c}0 \\
(0.40)\end{array}$ \\
\hline r3 & $\begin{array}{c}8 \\
(7.60)\end{array}$ & $\begin{array}{c}9 \\
(8.66)\end{array}$ & $\begin{array}{c}1 \\
(2.32)\end{array}$ & $\begin{array}{c}1 \\
(0.42)\end{array}$ \\
\hline r4 & $\begin{array}{c}7 \\
(7.20)\end{array}$ & $\begin{array}{c}8 \\
(8.20)\end{array}$ & $\begin{array}{c}3 \\
(2.20)\end{array}$ & $\begin{array}{c}0 \\
(0.40)\end{array}$ \\
\hline r5 & $\begin{array}{c}6 \\
(6.80)\end{array}$ & $\begin{array}{c}8 \\
(7.74)\end{array}$ & $\begin{array}{c}3 \\
(2.08)\end{array}$ & $\begin{array}{c}0 \\
(0.38)\end{array}$ \\
\hline
\end{tabular}

Table 2 shows the instructors factors in acquired teaching skills category. 
In terms of knowledge/mastery of the course, indicators used are as follows: k1- masters the scientific material of the course; $\mathrm{k} 2$ - demonstrates accurate and up-to-date knowledge of subject; k3 explains the course clearly and accurately; and k4 expresses the details of the lesson based on the level of students' understanding. Among these indicators, students noted that $\mathrm{k} 1$ and $\mathrm{k} 3$ obtained $95 \%$ of strongly agree and agree responses. This indicates that the instructors are much qualified to teach the course. However, results show that using df of 9, a calculated $\mathrm{x}^{2}$ value of 10.78 , which is less than critical value of 16.92 is an indication that there is no significant relationship between instructors' knowledge or mastery of the course factor and students' academic performance in the course. Furthermore, it means that the amount of difference between the expected and actual data is likely due to chance.

In terms of techniques used, indicators used are as follows: $\mathrm{t} 1$ - lecture; $\mathrm{t} 2$ - discussion; $\mathrm{t} 3$ exercises on whiteboard; t4 - group work; t5 laboratory applications; t6 - question and answer; $\mathrm{t} 7$ - running examples of programs; 18 - quizzes; and 19 - long examinations. Among these indicators, students noted that t6 obtained $95 \%$ of strongly agree and agree responses. Obviously, question and answer technique is considered by the students as the effective tool in teaching the lessons. However, results show that using df of 24 , a calculated $x^{2}$ value of 28.71 , which is less than critical value of 36.42 is an indication that there is no significant relationship between instructors' teaching techniques factor and students' academic performance in the course. Furthermore, it means that the amount of difference between the expected and actual data is likely due to chance.

In terms of resourcefulness in the use of instructional materials, indicators used are as follows: $\mathrm{r} 1$ - uses printed materials or resources such as updated editions of textbooks and reference books; r2 - uses whiteboards for illustrations or discussions of the concept or principle of the lessons; r3 - utilizes computer/multimedia projector for lesson demonstrations and machine problem exercises.; r4 - uses Internet for an up-to-date source of information and providing examples; and r5 uses familiar cases for students' projects. Among these indicators, students noted that $\mathrm{r} 3$ obtained $89 \%$ of strongly agree and agree responses. These results indicate that the instructors use her resourcefulness in order for the students to understand the computer programming lesson on the latter's level. However, the results show that using $\mathrm{df}$ of 12 , a calculated $\mathrm{x}^{2}$ value of 5.40, which is less than critical value of 21.03 is an that there is no significant relationship between instructors' resourcefulness in the use of instructional materials or machine problem examples/exercises factor and students' academic performance in the course. Furthermore, it means that the amount of difference between the expected and actual data is likely due to chance.

Next, follows are the factors of computer programming students as to their perceptions of the course, environmental learning conditions, emotional stimuli, and social stimuli.

Table 3. Perceptions of the course

\begin{tabular}{|c|c|c|c|c|}
\hline Indicators & SA & A & D & SD \\
\hline \multirow{2}{*}{$\mathrm{pc} 1$} & 8 & 7 & 3 & 0 \\
& $(7.38)$ & $(8.23)$ & $(2.15)$ & $(0.23)$ \\
\hline \multirow{2}{*}{$\mathrm{pc} 2$} & 6 & 6 & 3 & 2 \\
& $(6.97)$ & $(7.77)$ & $(2.03)$ & $(0.22)$ \\
\hline \multirow{2}{*}{$\mathrm{pc} 3$} & 7 & 9 & 2 & 0 \\
& $(7.38)$ & $(8.23)$ & $(2.15)$ & $(0.23)$ \\
\hline \multirow{2}{*}{$\mathrm{pc} 4$} & 7 & 9 & 2 & 0 \\
& $(7.38)$ & $(8.23)$ & $(2.15)$ & $(0.23)$ \\
\hline \multirow{2}{*}{$\mathrm{pc5}$} & 11 & 5 & 2 & 0 \\
& $(7.38)$ & $(8.23)$ & $(2.15)$ & $(0.23)$ \\
\hline \multirow{2}{*}{$\mathrm{pc6}$} & 8 & 7 & 2 & 0 \\
& $(6.97)$ & $(7.77)$ & $(2.03)$ & $(0.22)$ \\
\hline \multirow{2}{*}{$\mathrm{pc7}$} & 7 & 8 & 4 & 0 \\
& $(7.79)$ & $(8.69)$ & $(2.27)$ & $(0.24)$ \\
\hline \multirow{2}{*}{$\mathrm{pc} 8$} & 6 & 12 & 0 & 0 \\
& $(7.38)$ & $(8.23)$ & $(2.15)$ & $(0.23)$ \\
\hline \multirow{2}{*}{$\mathrm{pc} 9$} & 8 & 9 & 1 & 1 \\
& $(7.79)$ & $(8.69)$ & $(2.27)$ & $(0.24)$ \\
\hline \multirow{2}{*}{$\mathrm{pc} 10$} & 7 & 8 & 3 & 0 \\
& $(7.38)$ & $(8.23)$ & $(2.15)$ & $(0.23)$ \\
\hline \multirow{2}{*}{$\mathrm{pc} 11$} & 6 & 10 & 2 & 0 \\
& $(7.38)$ & $(8.23)$ & $(2.15)$ & $(0.23)$ \\
\hline \multirow{2}{*}{$\mathrm{pc} 12$} & 7 & 9 & 2 & 0 \\
& $(7.38)$ & $(8.23)$ & $(2.15)$ & $(0.23)$ \\
\hline \multirow{2}{*}{$\mathrm{pc} 13$} & 8 & 8 & 2 & 0 \\
& $(7.38)$ & $(8.23)$ & $(2.15)$ & $(0.23)$ \\
\hline
\end{tabular}

Indicators used in Table 3 are as follows: pc1 computer programming is a very interesting course; pc2 - computer programming helps me think logically; pc3 - working with analytical problems is interesting; pc4 - I want to solve computer programming exercises personally; pc5 - I want to solve computer programming exercises in groups; pc6 - computer programming is useful in any undertaking; pc7 - computer programming instructors should always give sufficient assignments; pc8 - I like to solve exercises in computer programming; pc9 - I am proud if I can solve computer programming exercises; pc10 computer programming is important in my daily activities; pc11 - I feel comfortable in my computer programming lectures; pc12 - I need more time to solve exercises in computer programming; and pc13 - I can apply computer programming skills in my future career. Among these indicators, students noted that pc8 obtained $95 \%$ agree responses. This indicates that the students like to solve computer programming exercises. However, results show that using df of 36 , a calculated $x^{2}$ value of 31.90 , which is less than critical value of 51.00 is an indication 
that there is no significant relationship between students' perceptions of the course and their academic performance in the course. Furthermore, it means that the amount of difference between the expected and actual data is likely due to chance.

Table 4. Environmental learning conditions

\begin{tabular}{|c|c|c|c|c|}
\hline Indicators & SA & A & D & SD \\
\hline e1 & $7(8.68)$ & $\begin{array}{c}10 \\
(8.38)\end{array}$ & $\begin{array}{c}1 \\
(1.35)\end{array}$ & $\begin{array}{c}1 \\
(0.60)\end{array}$ \\
\hline e2 & $9(7.76)$ & $\begin{array}{c}6 \\
(7.50)\end{array}$ & $\begin{array}{c}2 \\
(1.20)\end{array}$ & $\begin{array}{c}0 \\
(0.54)\end{array}$ \\
\hline e3 & $8(8.68)$ & $\begin{array}{c}9 \\
(8.38)\end{array}$ & $\begin{array}{c}1 \\
(1.35)\end{array}$ & $\begin{array}{c}1 \\
(0.60)\end{array}$ \\
\hline e4 & $7(8.22)$ & $\begin{array}{c}9 \\
(7.94)\end{array}$ & $\begin{array}{c}0 \\
(1.28)\end{array}$ & $\begin{array}{c}2 \\
(0.57)\end{array}$ \\
\hline e5 & $6(8.22)$ & $\begin{array}{c}9 \\
(7.94)\end{array}$ & $\begin{array}{c}3 \\
(1.28)\end{array}$ & $\begin{array}{c}0.57) \\
(0.57)\end{array}$ \\
\hline e6 & $\begin{array}{c}10 \\
(8.22)\end{array}$ & $\begin{array}{c}8 \\
(7.94)\end{array}$ & $\begin{array}{c}0 \\
(1.28)\end{array}$ & $(0.57)$ \\
\hline e7 & $\begin{array}{c}11 \\
(8.22)\end{array}$ & $\begin{array}{c}5 \\
(7.94)\end{array}$ & $\begin{array}{c}2 \\
(1.28)\end{array}$ & $\begin{array}{c}0.57) \\
(0.57)\end{array}$ \\
\hline
\end{tabular}

Indicators used in Table 4 are as follows: e1 - I appreciate courses with laboratory portions; e2 - I learn better through using computers; e3 - I can study well in a quiet room; e4 - I learn better when I am seated at the back; e5 - I learn better when the instructors write most of the time; e6 - I learn better when the room temperature is comfortable; and e 7 I can study well in properly lighted lecture/laboratory rooms. Among these indicators, students noted that e6 obtained $95 \%$ of strongly agree and agree responses. This indicates that students learn better when the room temperature is comfortable and well ventilated. However, results show that using df of 18 , a calculated $x^{2}$ value of 17.07 , which is less than critical value of 28.87 is an indication that there is no significant relationship between the students' environmental learning conditions and their academic performance in the course. Furthermore, it means that the amount of difference between the expected and actual data is likely due to chance.

Table 5. Emotional stimuli

\begin{tabular}{|c|c|c|c|c|}
\hline Indicators & SA & A & D & SD \\
\hline \multirow{2}{*}{ es1 } & $\begin{array}{c}4 \\
(6.62)\end{array}$ & $\begin{array}{c}10 \\
(8.17)\end{array}$ & $\begin{array}{c}3 \\
(2.10)\end{array}$ & $\begin{array}{c}0 \\
(0.11)\end{array}$ \\
\hline \multirow{2}{*}{ es2 } & $\begin{array}{c}7 \\
(6.62)\end{array}$ & $\begin{array}{c}7 \\
(8.17)\end{array}$ & $\begin{array}{c}3 \\
(2.10)\end{array}$ & $\begin{array}{c}0 \\
(0.11)\end{array}$ \\
\hline \multirow{2}{*}{ es3 } & 8 & 7 & 2 & 0 \\
& $(6.62)$ & $(8.17)$ & $(2.10)$ & $(0.11)$ \\
\hline \multirow{2}{*}{ es4 } & 7 & 10 & 0 & 0 \\
& $(6.62)$ & $(8.17)$ & $(2.10)$ & $(0.11)$ \\
\hline \multirow{2}{*}{ es5 } & 8 & 7 & 2 & 0 \\
& $(6.62)$ & $(8.17)$ & $(2.10)$ & $(0.11)$ \\
\hline \multirow{2}{*}{ es6 } & 5 & 11 & 1 & 1 \\
& $(7.01)$ & $(8.65)$ & $(2.22)$ & $(0.12)$ \\
\hline \multirow{2}{*}{ es7 } & 9 & 6 & 2 & 0 \\
& $(6.62)$ & $(8.17)$ & $(2.10)$ & $(0.11)$ \\
\hline \multirow{2}{*}{ es8 } & 5 & 10 & 2 & 0 \\
& $(6.62)$ & $(8.17)$ & $(2.10)$ & $(0.11)$ \\
\hline
\end{tabular}

\begin{tabular}{|c|c|c|c|c|}
\hline es9 & 7 & 6 & 4 & 0 \\
& $(6.62)$ & $(8.17)$ & $(2.10)$ & $(0.11)$ \\
\hline
\end{tabular}

Indicators used in Table 5 are as follows: es1 - I learn due to parents' expectations; es2 - I am driven by my desire to finish my studies; es 3 - I learn because of my ability to understand; es4 - I learn lessons and prove that exercises can be solved; es5 I learn even though courses are difficult; es6 - my effort is recognized by instructors and parents; es7 I learn better because success is the ultimate goal in life; es8 - I learn better when I am not disturbed, and; es9 - I learn better when everybody around supports me. Among these indicators, students noted that es 4 obtained $89 \%$ of strongly agree and agree responses. This indicates students learn the lessons better and prove that exercises given can be solved. However, results show that using df of 24, a calculated $x^{2}$ value of 19.64 , which is less than critical value of 36.42 is an indication that there is a significant relationship between students' emotional stimuli and their academic performance in the course. Furthermore, it means that the amount of difference between the expected and actual data is likely due to chance.

\begin{tabular}{|c|c|c|c|c|}
\multicolumn{5}{c}{ Table 6. Social stimuli } \\
\hline Indicators & SA & A & D & SD \\
\hline \multirow{2}{*}{ ss1 } & 8 & 8 & 1 & 1 \\
& $(7.15)$ & $(7.94)$ & $(2.38)$ & $(0.53)$ \\
\hline \multirow{2}{*}{ ss2 } & 7 & 7 & 3 & 0 \\
& $(6.75)$ & $(7.50)$ & $(2.25)$ & $(0.50)$ \\
\hline \multirow{2}{*}{ ss3 } & 4 & 8 & 3 & 1 \\
& $(6.35)$ & $(7.06)$ & $(2.12)$ & $(0.47)$ \\
\hline \multirow{2}{*}{ ss4 } & 8 & 7 & 2 & 0 \\
& $(6.75)$ & $(7.50)$ & $(2.25)$ & $(0.50)$ \\
\hline
\end{tabular}

Indicators used in Table 6 are as follows: ss 1 - I learn better in a group of classmates of the same intellectual capacity; ss2 - I enjoy doing by practicing computer programming exercises all by myself; ss3 - I learn through self-study, and; ss4 - I need to interact with my classmate to learn. Among these indicators, students noted that ss1 obtained $84 \%$ of strongly agree and agree responses. The results indicate that the students learn better in a group of the same intellectual level. However, results show that using df of 9 , a calculated $\mathrm{x}^{2}$ value of 4.86 which is less than critical value of 16.92 is an indication that there is no significant relationship between students' social stimuli and their academic performance in the course. Furthermore, it means that the amount of difference between the expected and actual data is likely due to chance.

It was revealed that based on the results obtained, the hypothesis that there is a significant relationship between the factors pertaining to instructors' characteristics as perceived by students and the students' academic performance in basic computer programming course has been rejected. The samples 
given on this paper do not support the hypothesis of difference/relationship. However, as stated by Akiri and Ugborugbo [1], the quality of education depends on the teachers as reflected in the performance of their duties. This means that the quality of teaching that they have provided for the students is a reflection of the latter's academic performance in a particular course. The respondents perceived and revealed that the course seems difficult to grasp and requires higher analytical skills that the lack of which continuously hinders them from learning and improving their academic performance.

\section{Conclusions}

Computer Programming I course of IT Department of KSU covers the foundation of the basic computer programming. This is the first stage where the students will be able to develop further their analytical skills that they will use throughout their study of the chosen IT career or field. This is one of the courses that students find difficult to comprehend and cope with.

The findings gathered and revealed, given the numerous indicators for each possible factor that influence students' academic performance in the course, the authors found out that there is no significant relationship between the instructors' factors as perceived by the students and the latter's academic performance in the course.

On the other hand, students noted the most important to least important factor that will help them learn the course, ease its difficulty and boost their academic performance. In terms of instructors' factors as perceived by the students: first in rank is classroom management skill; second in rank are personality, knowledge/mastery of the course and teaching techniques used, and; last in rank are communication skills and resourcefulness in the use instructional materials or machine problem examples/exercises.

Arranged according to each factor's rank, indicators of each factor were noted as well from most important to least important. Firstly, concerning instructors' classroom management skills factor that could assist them in learning the course: first in rank is "comes to classroom on time"; second in rank are "comes to class well prepared" and "checks attendance"; third in rank are "gives sufficient time for different topics or lessons", "maintains order and discipline in the classroom", "gets the attention of the students who do not listen, are frequently absent and have other deficiencies" and "achieves teaching objectives for the particular subject, lesson, or laboratory activities within a reasonable period of time", and; last in rank is "administers examinations/tests effectively and returns corrected papers and other students' work promptly." Secondly, concerning instructors' personality factor that could assist them in learning the course: first in rank are "approachable outside the classroom for consultation", "fair when dealing with students and when giving grades", "encourages student to ask questions and express opinion freely", "observes proper clothes/dress at all times", and "shows evidence of professional and cultural growth"; second in rank are "shows enthusiasm when teaching", "respects and accepts students' ideas, suggestions and limitations", "displays willingness to repeat the lesson when necessary", "uses free time effectively/efficiently", and "shows creativity and energy in their performance"; last in rank are "observes the Instructors' Code of Ethics and other pertinent rules and regulations of the university", "understands the example in moral and ethical behavior to students, peers and the community", and "makes jokes that release tension but not at the expense of another student in the class." Thirdly, concerning instructors' knowledge and mastery of the course factor that could assist them in learning the course: first in rank are "masters the scientific material of the course" and "explains the course clearly and accurately"; second in rank is "demonstrates accurate and up-to-date knowledge of subject", and; last in rank is "expresses the details of the lesson based on the level of students' understanding." Fourthly, concerning instructors' teaching techniques factor that could assist them in learning the course: first in rank is question and answer; second in rank are lecture, discussion and exercises on whiteboard; third in rank are laboratory applications, quizzes and long examinations; last in rank are running examples of programs and group work. Fifthly, concerning instructors' communication skills factor that could assist them in learning the course: first in rank is "has the ability to explain subject matter clearly"; second in rank are "ask questions relevant to the course" and "expresses her own ideas about the subject matter for particular sessions/classes/meetings"; third in rank is "use of English language as a medium of communication in teaching", and; last in rank is "gives facts or opinions about content or procedures of the subject matter for each class meeting." Lastly, concerning instructors' resourcefulness in the use of instructional materials or machine problem examples/exercises factor that could assist them in learning the course: first in rank is "utilizes computer/multimedia projector for lesson demonstrations and machine problem exercises"; second in rank is uses whiteboards for illustrations or discussions of the concept or principle of the lessons"; third in rank are "uses printed materials or resources such as updated editions of textbooks and reference books" and "uses Internet for an up-to-date source of information and providing examples", and; last in rank is "uses familiar cases for students' projects." 
And with regards to students' factors, they noted the most important to least important factor that will contribute to boost their academic performance in the course, the first in rank is their perceptions of the course and environmental learning conditions, second in rank is their emotional stimuli, and last in rank is their social stimuli.

Arranged according to each factor's rank, indicators for these factors have been noted as well by the student. Firstly, concerning their perceptions of the course factor that could assist them in learning the course: first in rank is "I like to solve exercises in computer programming"; second in rank is "I am proud if I can solve computer programming exercises"; third in rank are "working with analytical problems is interesting", "I want to solve computer programming exercises personally", "I want to solve computer programming exercises in groups", "I feel comfortable in my computer programming lectures", "I need more time to solve exercises in computer programming", and "I can apply computer programming skills in my future career"; fourth in rank are "computer programming is a very interesting course", "computer programming is useful in any undertaking", "computer programming instructors should always give sufficient assignments", and "computer programming is important in my daily activities", and; last in rank is "computer programming helps me think logically." Secondly, concerning their environmental learning conditions factor that could assist them in learning the course: first in rank is "I learn better when the room temperature is comfortable"; second in rank are "I appreciate courses with laboratory portions" and "I can study well in a quiet room"; third in rank are "I learn better when I am seated at the back" and "I can study well in properly lighted lecture/laboratory rooms", and; last in rank are "I learn better through using computers" and "I learn better when the instructors write most of the time." Thirdly, concerning their emotional stimuli factor that could assist them in learning the course: first in rank is "I learn lessons and prove that exercises can be solved"; second in rank is "my effort is recognized by instructors and parents"; third in rank are "I learn because of my ability to understand", "I learn even though courses are difficult", "I learn better because success is the ultimate goal in life" and "I learn better when I am not disturbed", and; last in rank are "I learn due to parents' expectations", "I am driven by my desire to finish my studies", and "I learn better when everybody around supports me." Lastly, concerning their social stimuli factor that could assist them in learning the course: first in rank is "I learn better in a group of classmates of the same intellectual capacity"; second in rank is "I need to interact with my classmate to learn"; third in rank is "I enjoy doing by practicing computer programming exercises all by myself', and; last in rank is I learn through self-study.

The authors concluded that those factors and indicators that were ranked by the students could greatly assist the students, school administrators, heads/directors and instructors in the process of teaching and learning. This will be a tool that will help the university to have a comprehensive evaluation on how they will be able to assist the students and instructors to boost the students' academic performance in computer programming courses through the use of those factors that are noted by the student themselves. In this way, teaching techniques will further be improved and quality of IT education in Saudi Arabia will be more uplifted.

\section{Recommendation}

Despite of the results obtained, the authors recommend further study and observation of the students' performance using a specific technique to resolve the issues of the course difficulty and further improvement of the techniques in teaching programming courses.

\section{Acknowledgment}

The authors would like to express their gratitude and heartfelt thanks to the IT Department of the College of Computer and Information Sciences of KSU and to the doctors of philosophy, particularly Dr. Areej Al-Wabil and Dr. Sihem Mostafai, for their support for this work.

\section{References}

[1] A. A. Akiri and N. M. Ugborugbo, "Teachers' Effectiveness and Students' Academic Performance in Public Secondary Schools in Delta State, Nigeria" [Online]. Stud Home Comm Sci 2009, Vol. 3, No. 2, pp. 107-113, Available: http://www.krepublishers.com/02Journals/S-Abst-PDF/HCS-03-2-107-09-094-Akiri-A-

A/HCS-03-2-107-09-094-Akiri-A-A-Tt.pdf (Accessed: March 21, 2011).

[2] A. Olalekan, "Students and Teachers' Perception of the Causes of Poor Academic Performance in Ogun State Secondary Schools [Nigeria]: Implications for Counselling for National Development" [Online]. European Journal of Social Sciences - 2010, Vol. 13, No. 2, Available: http://www.eurojournals.com/ejss_13_2_08.pdf (Accessed: January 2, 2012).

[3] A. Robins, J. Rountree, and N. Rountree, "Learning and Teaching Programming: A Review and Discussion" [Online]. Computer Science Education 2003, Vol. 13, No. 2, pp. 137-172, Available at : http://folk.uio.no/christho/inf3240/downloads/RobinsRev.p df (Accessed: March 21, 2011). 
[4] C. Rogerson and E. Scott (n.d.), "The Fear Factors: How it Affects Students Learning to Program in a Tertiary Environment" [Online], The Journal of Information Technology Education, Available at: http://jite.org/documents/Vol9/JITEv9p147171Rogerson80 3.pdf (Accessed: March 21, 2011).

[5] E. A. Chaparro, A. Yuksel, P. Romero, and S. Bryant (n.d.), "Factors Affecting the Perceived Effectiveness of Pair Programming in Higher Education" [Online], Psychology of Programming Interest Group 2005, Sussex University, Available at: http://citeseerx.ist.psu.edu (Accessed: March 21, 2011).

[6] F. L. Want and T. Wong (2008), "Designing Programming Exercises with Computer Assisted Instruction" [Online], Hybrid Learning and Education, Vol. 5169, Available at: http://www.cs.cityu.edu.hk / ichl2008/LNCSProceedings/ICHL2008_FuLeeWang_11 pages.pdf (Accessed: March 21, 2011).

[7] H. Tie and I. N. Umar (2010), "The Impact of Learning Styles and Instructional Methods of Students' Recall and Retention in Programming Education" [Online], The $18^{\text {th }}$ International Conference on Computers in Education (ICCE) 2010, Available at: http://www icce2010.upm.edu.my/papers/c2/short\%20paper/ C2SP239.pdf (Accessed: March 21, 2011).

[8] H. Xiaohui (2006), "Improving Teaching in Computer Programming by Adopting Student-Centered Learning Strategies" [Online], The China Papers, November 2006, Available at: http://sydney.edu.au/science/ uniserve_science/pubs/china/vol6/IT3.pdf (Accessed: March 21, 2011).

[9] M. N. Ismail, N. A. Ngah, and I. N. Umar (n.d.), "Instructional Strategy in the Teaching of Computer Programming: A need Assessment Analyses" [Online], TOJET: The Turkish Online Journal of Educational Technology - April 2010, Vol. 9, No. 2, Available: http://www.tojet.net /articles/9214.pdf (Accessed: March 21, 2011).

[10] M. Pedroni (2003), “Teaching Introductory Programming with Inverted Curriculum Approach" [Online], Available: http://e-collection.ethbib.ethz.ch /eserv/eth:28338/eth-28338-01.pdf (Accessed: March 21, 2011).

[11] R. A. Garcia (2006), "Factors Affecting Student' Performance in Basic Computer Programming: An Answer to Business and Industry's Needs," (Unpublished master's thesis). Laguna College of Business and Arts, Calamba City, Philippines.

[12] S. Wiedenbeck, D. Labelle, and V.N.R. Kain (2004), "Factors Affecting Course Outcomes in Introductory Programming" [Online], Psychology of Programming Interest Group, Ireland, Available: http://citeseerx .ist.psu.edu/ (Accessed: March 21, 2011).

[13] S. Winters, "Computer Programming Basics - Getting Started the Easy Way" [Online], Available at: http://ezinearticles.com/?Computer-Programming-Basics--
-Getting-Started-the-Easy-Way\&id=4153423 (Accessed: March 21, 2011).

[14] The Communications and Information Technology Commission (CITC). IT Report 2010 Kingdom of Saudi Arabia. Available at: http://ww.citc.gov.sa (Accessed: March 21, 2011).

[15] V. Lucio (2012), "The IT Industry is begging for women workers" [Online], Available: http://www.mysanantonio.com/news/local_news/article/Th e-IT-industry-is-begging-for-women-workers-3781840. php\#ixzz23XX0H400 (Accessed: October 18, 2012). 